Accepted in Diversity and Distributions as a "Biodiversity Viewpoint"

doi: 10.1111/ddi.12469 (2016)

\title{
The Lost World's pristinity at risk
}

Running title: The Lost World at risk

by

\section{Valentí Rull $^{1 *}$, Teresa Vegas-Vilarrúbia ${ }^{2}$ and Elisabet Safont ${ }^{2}$}

${ }^{1}$ Institute of Earth Sciences Jaume Almera (ICTJA-CSIC), 08028 Barcelona, Spain

${ }^{2}$ Department of Ecology, University of Barcelona, 08028 Barcelona, Spain

${ }^{*}$ Correspondence: Valentí Rull, Institute of Earth Sciences Jaume Almera (ICTJA-CSIC), C. Solé I Sabarís s/n, 08028 Barcelona, Spain. E-mail vrull@ictja.csic.es 


\section{Abstract}

The Guayana Highlands (GH) are virtually pristine environments and constitute a unique natural laboratory to study the biogeographical and evolutionary origin of the neotropical biota. In addition, the GH provide most of the water of the Guayana region, which feeds the more important tributaries of the Orinoco and the Amazon basins. However, the biota and the ecosystems of the $\mathrm{GH}$ are in danger of being profoundly altered by current human activities. Recent studies have identified the presence of aggressive invader plant species (e.g. Poa annua and Polypogon elongatus) and infectious faecal bacteria (Helicobacter pilori), both carried by tourists, which could deeply affect biodiversity and ecological performance of terrestrial and aquatic GH ecosystems. If these hazards are not controlled as soon as possible, the potential consequences could disturb not only the GH ecosystems but also those of the rest of the Guayana region. We still have time to find solutions and implement specific regulations before the mentioned threats become uncontrollable. The GH are within a national park and other conservation figures but a management plan is lacking; therefore, current conservation rules are insufficient to deal with the newly detected menaces. We propose an international initiative, including all countries of the Guayana Shield, to take immediate actions. Otherwise, we are in danger of losing one of the few pristine biomes that remain in the world.

Keywords: biodiversity conservation, faecal bacteria, Guayana Shield, invader plants, national parks, neotropical biodiversity, pristine biomes 


\section{Introduction}

The Guayana Highlands (GH), the Lost World of Arthur Conan Doyle, are among the few environments in the world that remain virtually pristine. Therefore, the GH constitute an unparalleled natural laboratory to study the evolutionary origin of the neotropical biota and the natural ecological dynamics of the communities it contains (Rull, 2010). In addition, the GH are the source for most of the water of the Guayana region. The rivers are among the most important tributaries of the Orinoco and the Amazon basins. The Guayana region has been considered an international conservation priority after the Paramaribo Declaration and its revisions (Huber \& Foster 2003; Bernard et al., 2011). However, the pristine nature of the GH is seriously challenged by what could be considered the first signs of direct human impact on the composition and function of the GH ecosystems. To date, the main threats for the $\mathrm{GH}$ environments were mechanical disturbances of vegetation, notably trampling and plant mutilation, due to regular touristic visits. Recent studies have identified other menaces, such as the introduction of non-native species and the contamination of waters, which could affect ecological performance and ecosystem services. If these hazards are not controlled as soon as possible, the potential consequences could disturb not only the $\mathrm{GH}$ terrestrial and aquatic ecosystems but also those of the rest of the Guayana region. The purpose of this note is to highlight these incipient risks and discuss potential solutions.

\section{The Guayana Highlands: overview}

The GH are the flat summits of the approximately 60 sandstone/quartzite table mountains of the neotropical Guayana/Guiana Shield Ecoregion (Fig. 1). Its unique biotic features led to the definition of the Pantepui biogeographic province (Huber, 1994). The extent of these summits is highly variable, from less than one to approximately $2500 \mathrm{~km}^{2}$, with a total area of ca. 6000 
$\mathrm{km}^{2}$. The elevation ranges from 1500 to $3000 \mathrm{~m}$ (Huber 1995). The GH, which exhibit biodiversity and endemism patterns similar to oceanic islands (Rull, 2009), are fairly isolated from the surrounding lowlands and uplands of the Amazon and Orinoco basins from where they emerge as an archipelago of islands suspended in the air. The GH are remote and inaccessible by usual means and only a few summits can be reached by foot. The indigenous people inhabiting the surrounding lands call these table mountains tepuis, meaning "rock buds", and consider the summits as sacred lands where the gods live and humans are banned. Consequently, they do not climb to these summits. Other cultures have shown little interest in the $\mathrm{GH}$ because, in addition to their remoteness and inaccessibility, there are no economically profitable resources on them. Activities such as mining, agriculture, livestock or forestry are hindered by the special geologic, edaphic and biotic conditions.

Tourism and scientific exploration are the only activities that have been developed on Pantepui, using mainly helicopters as transportation (Huber, 1995). Fortunately, there is no tourist infrastructure atop the tepuis to facilitate visitation, which maintains the lack of human impact on the summit. The $\mathrm{GH}$ are protected by several designations including several national parks, the Alto Orinoco-Casiquiare Biosphere Reserve and the Canaima World Heritage Site. The tepuis themselves were declared a natural monument in 1990 (Huber, 1995). However, in practice, the existing infrastructure is not enough to meet the conservation regulations in such a vast and remote region as Pantepui. In 1989, the official permits to visit all tepui summits were suspended. Only two summits remained open to tourists, the Auyán-tepui and the Roraima-tepui, which are accessible by foot after traversing long, but relatively easy, trails (Huber, 1995). For other tepuis, special permits are required for both tourist and scientific activities, which can be obtained (or not) after a long, complex and often erratic process (Rull \& Vegas-Vilarrúbia, 2008). The most visited tepui, by far, is the Roraima, situated at the triple boundary between Venezuela, Guyana and Brazil, with a summit area of $34.4 \mathrm{~km}^{2}$ and $2810 \mathrm{~m}$ 
of maximum elevation. This tepui receives between 3000 and 4000 tourists per year (da Silva et al., 2011) and, in spite of current conservation rules, has resulted in obvious vegetation trampling and the presence of garbage, food scraps, toilet paper, human excrement and graffiti around the camping areas.

\section{Novel threats}

A recent study by Safont et al. (2014) identified 13 exotic plants introduced by humans. Two of these plants, the potato (Solanum tuberosum) and the tomato (Lycopersicon esculentum), are cultivated elsewhere, and may not represent a serious danger because they depend on humans for their proliferation in wild conditions. Other non-native species introduced by humans atop the Roraima are the compositae Sonchus oleraceus and Gnaphalium elegans, the sedges Rhynchospora schomburgkiana and Eleocharis filicumis, the rush Juncus effusus, the rosaceae Rubus urticifolius and five grasses: Avenella flexuosa, Cinna poiformis, Vulpia myuros, Poa annua and Polypogon elongatus. At present, most of these species occur in small and localized populations, but $P$. elongatus, a well-known invasive plant elsewhere (Holm et al. 1997), is more abundant, and its patterns of occurrence in the Roraima summit fulfil the criteria to be considered naturalized and invasive (Richardson et al., 2000; Safont et al., 2014). P. annua, a species of cosmopolitan distribution that has been recognized as one of the most aggressive weeds (Holm et al., 1997), has grown atop the Roraima since at least 2002 (Delascio \& Nozawa, 2010); hence, it also has potential for becoming invasive. The potential invasion of the whole Roraima summit by one or more of these aggressive species could significantly alter the vegetation patterns and, as a result, the ecological function of the terrestrial ecosystems. In addition, $P$. elongatus and $P$. annua can be dispersed by wind, water and animals; therefore, their potential for colonizing other tepuian summits is high. Their spontaneous migration has not been confirmed yet but warrants investigation as soon as possible. 
Another study that is in process of publication (Fernández-Delgado et al., 2016) identified several bacteria in the Roraima freshwaters, including a species of Helicobacter with high genetic similarity (99-100\% of the $16 \mathrm{~S}$ rRNA sequences) to $H$. pylori and $H$. nemestrinae. The second species was first isolated from a pig-tailed macaque (Macaca nemestrina) (Brondson et al. 1991) but was further considered to be a strain of $H$. pylori, of which $H$. nemestrinae is recognized now as a synonym (Suerbaum et al., 2002). H. pylori is a well-known spiral microbial dweller of the human gastrointestinal tract, notably the stomach, and the recognized cause of gastritis, ulcers and cancer. H. pylori is present in more than the half of the world's population and is considered the most common chronic bacterial infection in mankind (Weaver et al., 1999). However, the prevalence of H. pylori in the Paraitepuy Pemon community, which is located at the base of the Roraima and provides the indigenous guides for tourists to climb to the tepui, is very low (11\%) (Fernández-Delgado et al., 2016). Therefore, these authors attribute the presence of the microbe mainly to tourists. They do not dismiss a potential wildlife origin, but this is a remote possibility, as no known primates live on the Roraima summit. The only mammals found so far are the mouse Podoxymys roraimae (PérezZapata et al., 1992) and the brown-nosed coati Nasua nasua (Havelková et al., 2006). The Roraima water samples infected by $H$. pylori are located near the camp sites, therefore, the most probable origin of this microbe are human faeces from tourists. The probability of $H$. pylori transmission to upland and lowland rivers and, as a consequence, to be widespread across the fluvial network, is high. In this way, the Roraima could become an infection focus in a region where the prevalence of $H$. pylori in humans is low. 


\section{Current conservation status}

In addition to the Roraima, where controlled visits are allowed, tourists and practitioners of extreme sports (for example, rock climbing or skydiving) often visit other tepuis. These activities are usually performed illegally without the corresponding permits, making it difficult to control their development and potential consequences. Several local and foreign companies organize eco-tourism, adventure and scientific (and pseudoscientific) expeditions of dubious legality. Biopiracy practices, for example, earning pharmaceutical patents or selling exotic plants illegally, are also common. All these activities are uncontrolled and may disturb the tepuian ecosystems in a similar fashion as is occurring on the Roraima summit. However, the difficulty of obtaining fieldtrip permits prevents scientific study of the true impact of the human presence on most tepuian summits. Unfortunately, the proliferation of illegal activities reinforces the restrictive nature of permit policies, even for researchers to study the tepuian ecology to inform conservation practices (Rull \& Vegas-Vilarrúbia, 2008).

The latest thorough environmental evaluation of the Canaima National Park, to which the Roraima and many other tepuian summits belong, was issued nine years ago (Novo \& Díaz, 2007). This evaluation concludes that the conservation status of the tepuian summits, in general, is good, but the level of threat is high, especially for biodiversity. The report also identifies a number of drawbacks for a suitable conservation strategy: (i) the low level of funding, with the corresponding lack of sufficient and adequate coordination of efforts; (ii) the scarcity, high turnover and incomplete training of the personnel in charge of daily field surveillance, which results in low rates of compliance for conservation rules; (iii) the huge range of the park and the remoteness of many protected areas, which makes access very difficult; (iv) the number and diversity of actors and stakeholders, including governmental, private and indigenous interests; $(v)$ the absence of a mechanism of exchange among people 
and organizations with interests in the park; and (vi) the lack of a definite management plan for the park.

\section{Conclusions and some proposals}

The incipient ecosystem disturbances atop the Roraima discussed above, as well as other eventual disruptions, need to be monitored and studied in greater depth for a better diagnosis of the situation. The same is true for the rest of the tepuis, particularly those with the most visitors. Ideally, such studies would be part of a general management plan, but, in its absence and given the urgency of the problems mentioned above, we suggest developing immediate assessment actions leading to a better protection status for these specific issues. We still have time to find solutions and implement specific regulations before the mentioned threats become uncontrollable. Solutions should ideally include both preventive and corrective measures, which should be agreed upon by the different conservation actors and stakeholders. The vastness, remoteness and complicated topography of the GH require a large and complex infrastructure to assure compliance with conservation regulations. Even the best legislation might be ineffective if its implementation is constrained by limited resources.

The multinational character of the $\mathrm{GH}$ and the Guayana region as a whole, which encompasses terrains belonging to six countries (Brazil, Colombia, French Guiana, Guyana, Surinam and Venezuela), requires an international cooperative initiative to ensure the conservation of the Guayana region. The Guiana Shield Facility (GSF) (http://guianashield.org/) would be a suitable platform for such an initiative as the entire $\mathrm{GH}$ and their surrounding uplands and lowlands are included in the Guiana Shield. In the GH, the GSF has defined four highest-priority conservation areas from a biological point of view: the Southern Upland and Tepui Area (6), the Northwestern Upland and Tepui Area (11), the central Upland and Tepui Area (13) and the 
Eastern Upland and Tepui Area (18) (Huber \& Foster, 2003; Bernard et al., 2011) (Fig. 1).

Therefore, the need for urgent conservation activities in the $\mathrm{GH}$ is already recognized by the

GSF. The next step would be to take action, and the case of the Roraima presented here would be an excellent opportunity. Otherwise, we are in danger of losing one of the few pristine biomes that remain in the world. 


\section{References}

Bernard, C., Upgren, A. \& Honzák, M. (2011) Review of the Guiana Shield Priority Setting Outcomes: Narrative Report. Conservation International, Georgetown.

Brondson, M.A., Goodwin, C.S., Sly, L., Chilvers, T. \& Schoenknecht F.D. (1991) Helicobacter nemestrinae sp. nov., a spiral bacterium found in the stomach of a pigtailed macaque (Macaca nemestrina). International Journal of Systematic Bacteriology, 41, 148-153. da Silva, R.D.M., da Cruz, J. \& Py-Daniel, V. (2011) Monte Roraima na América do Sul, Venezuela: Destino mundial do turismo de naturaleza. Pasos, 9, 411-422.

Delascio. F. \& Nozawa, S. (2010) Poa annua L. y Polypogon elongatus Kunth (Poaceae). Dos nuevas especies exóticas para la flora de la Guayana Venezolana. Acta Botanica Venezuelica, 33, 357-361.

Fernández-Delgado, M., Giarrizzo, J.G., García-Amado, M.A., Contreras, M., Salazar, V., Barton, H. \& Suárez, P. (2016) Evidence of Helicobacter spp. in freshwaters from Roraima Tepui, Guayana Shield, South America. Antoine van Leeuwenhoeck, doi: $10.1007 / \mathrm{s} 10482-016-0658-9$

Havelková, P., Robovsky, J., Audy, M. \& Díaz de Pascual, A. (2006) Brown-nosed coati (Nasua nasua vittata) on the Roraima tepui (Carnivora: Procymonidae). Lynx (Praha), 37, 123130.

Holm, L.G., Holm, E., Pancho, J.V. \& Herberger, J.P. (1997) World weeds: natural histories and distribution. Wiley, New York.

Huber, O. (1994) Recent advances in the phytogeography of the Guayana region, South America. Mémoire de la Société de Biogéographie (3e série), 4, 53-63.

Huber O. 1995. Conservation of the Venezuelan Guayana. Flora of the Venezuelan Guayana. Volume 1. Introduction (ed. by P.E. Berry, B.K. Holst \& K. Yatskievych), pp. 193-218. Missouri Botanical Graden Press, St. Louis. 
Huber, O. \& Foster, M.N. (2003) Conservation priorities for the Guayana Shield. Conservation International, Washington.

Novo, I. \& Díaz, D. (2007) Informe final de la evaluación del Parque nacional Canaima, Venezuela, como sitio de Patrimonio Natural de la Humanidad. INPARQUES, Caracas.

Pérez-Zapata, A., Lew, D., Aguilera, M. \& Reig, O.A. (1992) New data on the systematics and karyology of Podoxymys roraimae (Rodentia, Cricetidae). Zeitschrift für Säugetierkunde, 57, 216-224.

Richardson, D.M., Pyšek, P., Remánek, M., Barbour, M.G., Panetta, F.D. \& West, C.J. (2000) Naturalization and invasion of alien plants: concepts and definitions. Diversity and Distributions, 6, 93-107.

Rull, V. (2009) Pantepui. Encyclopedia of islands (ed. by R.G. Gillespie \& C. Clague), pp. 717720. University of California Press, Berkeley.

Rull, V. (2010) The Guayana Highlands: a natural laboratory for the biogeographical and evolutionary study of the neotropical flora. Urumaco and Venezuelan paleontology. The fossil record of the northern Neotropics (ed. by M.M. Sánchez-Villagra, O. Aguilera \& A.A. Carlini), pp. 84-102. Indiana University Press, Bloomington.

Rull, V., Vegas-Vilarrúbia, T. (2008) Biopiracy rules hinder conservation efforts. Nature, 453, 26. Safont, E., Rull, V., Vegas-Vilarrúbia, T., Holst, B.K., Huber, O., Nozawa, S., Vivas, Y. \& Silva, A. (2014) Establishing a baseline of plant diversity and endemism on a neotropical mountain summit for future comparative studies assessing upward migration: an approach from biogeography and nature conservation. Systematics and Biodiversity, 12, 292-314.

Suerbaum, S., Kraft, C., Dewhirst, F.E. \& Fox, J.G. (2002) Helicobacter nemestrinae ATCC $49396 \mathrm{~T}$ is a strain of Helicobacter pylori (Marshall et al. 1985) Goodwin et al. 1989, and Helicobacter nemestrinae Bronsdon et al. 1991 is therefore a junior heterotypic 
synonym of Helicobacter pylori. International Journal of Systematic and Evolutionary Microbiology, 52, 437-439.

Weaver, L.T., Shepherd, A.J., Doherty, C.P., McColl, K.E.L. \& Williams, C.L. (1999) Helicobacter pylori in the faeces? Quarterly Journal of Medicine, 361, 361-364. 


\section{Figure caption}

Figure 1. A) Map of northern South America indicating the Guiana Shield Ecoregion (black contour). The Guayana Highlands lie within the white circle and the Roraima-tepui is indicated by a yellow star. The numbers are the high-priority conservation areas of the Guiana Shield Facility (GSF) (http://guianashield.org/). Radar image courtesy of NASA/JPL/NIMA. B) General view of the Roraima-tepui with the Gran Sabana uplands in the foreground (Photo: V. Rull). 


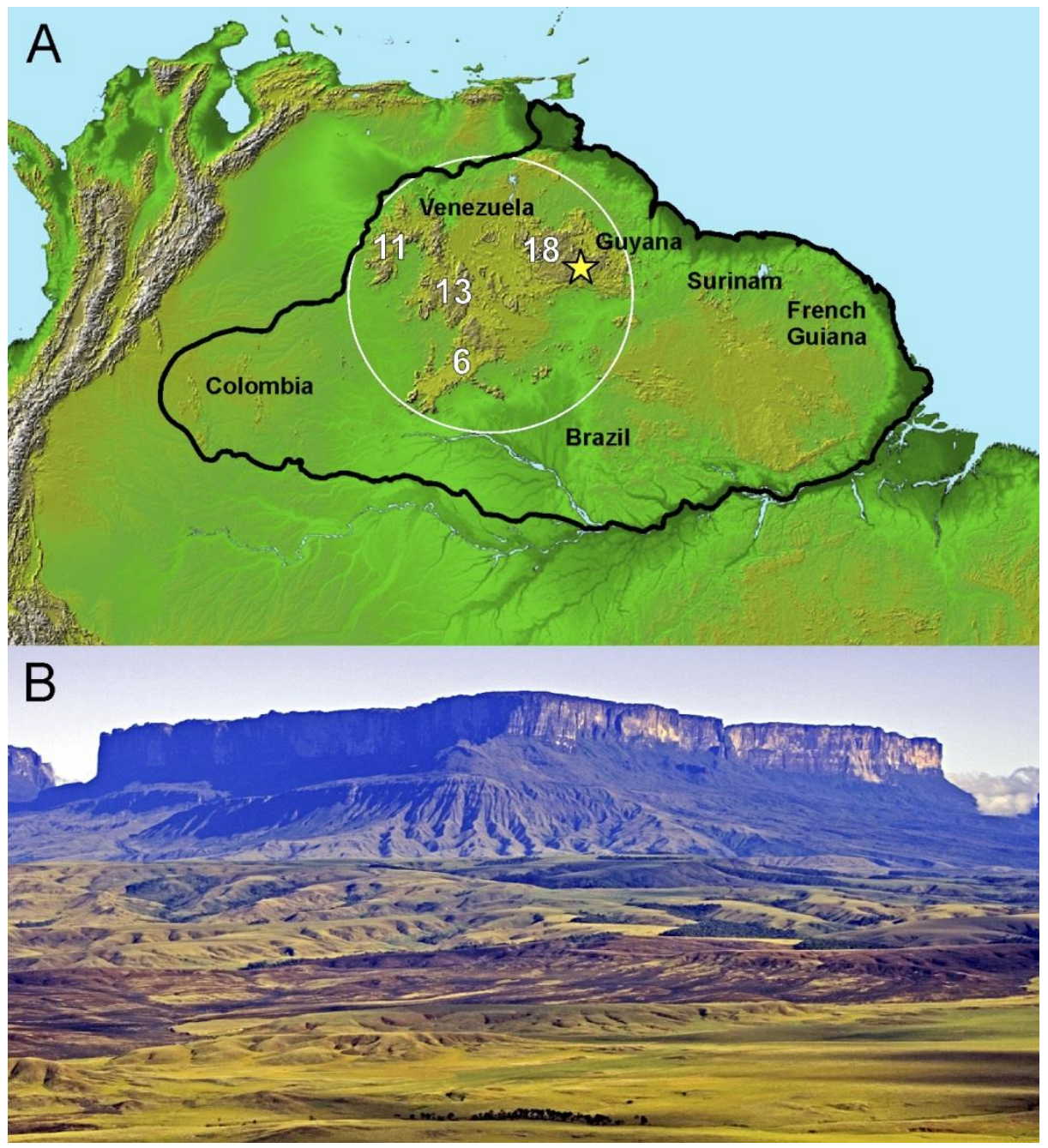

Figure 1 


\section{Biosketches}

Valentí Rull is a Senior Researcher of the Institute of Earth Sciences Jaume Almera (CSIC). His interests include the use of paleoecology for the understanding of biogeographical and ecological patterns and processes and its application to biodiversity conservation.

Teresa Vegas is Aggregate Professor at the University of Barcelona (dep. Ecology). Her research interests include limnology, paleolimnology, climate change and ecosystem responses, biodiversity conservation and environmental management.

Elisabet Safont is a Postdoctoral Researcher at the University of Barcelona (Dep. Ecology). She is interested in biotic responses to climate changes, high-mountain paleoecology, neotropical biodiversity and biogeography, and biodiversity conservation in the face of global change. 